\begin{abstract}
ARKADIUSZ MRÓZ
Wydział Prawa Kanonicznego

Uniwersytetu Kardynała Stefana Wyszyńskiego w Warszawie

ORCID 0000-0002-1508-4273
\end{abstract}

\title{
ALIENACJA DOKONANA BEZ DOCHOWANIA KANONICZNYCH WYMOGÓW
}

Treść: Wprowadzenie. - 1. Alienacja dóbr kościelnych osób prawnych i kanoniczne wymogi jej dokonania. - 2. Kanonizacja przepisów prawa cywilnego dotyczących umów i zobowiązań. - 3. Kanoniczne skutki alienacji dokonanej bez dochowania prawnych wymogów. - Zakończenie

\section{Wprowadzenie}

Kościelne prawo majątkowe kanonizuje przepisy prawa cywilnego dotyczące umów i zobowiązań, czego skutkiem jest konieczność stosowania ich przy dokonywaniu przez kościelne osoby prawne czynności mających za przedmiot dobra doczesne Kościoła. Jednocześnie, prawo kanoniczne przewiduje szczególne, nieznane polskiemu prawu cywilnemu, wymogi alienacji dóbr kościelnych. Na gruncie prawa świeckiego następuje z kolei recepcja prawa kanonicznego, nakazująca uwzględnianie norm kościelnych przy ocenie skuteczności takich czynności prawnych z punktu widzenia polskiego prawa cywilnego. Kwestia ważności czynności dokonywanych na styku prawa kanonicznego i państwowego oraz skuteczności umów zawieranych przez kościelne osoby prawne $z$ innymi podmiotami stanowi żywe w praktyce oraz niezwykle istotne dla bezpieczeństwa i pewności obrotu zagadnienie.

Niniejszy artykuł jest pierwszym z dwóch artykułów, prezentujących rozważania dotyczące kanonicznej i cywilnoprawnej 
skuteczności alienacji dóbr, dokonanej przez kościelną osobę prawną, bez dochowania wymogów przewidzianych prawem kanonicznym. Zawarte w artykułach rozważania stanowią próbę odpowiedzi na pytania o możliwość uznania kanonicznych wymogów alienacyjnych na forum świeckim oraz skuteczność alienacji dokonanej bez ich dochowania na gruncie prawa kanonicznego i polskiego prawa cywilnego.

W artykule zawarto rozważania dotyczące alienacji dóbr kościelnych i jej kanonicznych wymogów, kanonizacji przepisów prawa cywilnego dotyczących umów i zobowiązań oraz kanonicznej skuteczności alienacji dokonanej bez dochowania przewidzianych prawem warunków.

W kolejnym artykule zaprezentowane zostaną rozważania dotyczące recepcji prawa kanonicznego do polskiego systemu prawnego oraz cywilnoprawnej skuteczności alienacji dokonanej przez kościelną osobę prawną bez dochowania kanonicznych wymogów.

\section{Alienacja dóbr kościelnych osób prawnych i kanoniczne wymogi jej dokonania}

Zgodnie z kan. 1254 KPK ${ }^{1}$, Kościół katolicki na podstawie prawa wrodzonego, niezależnie od władzy świeckiej, może dobra doczesne nabywać, posiadać, zarządzać i alienować, dla osiągnięcia właściwych sobie celów. Zdolność majątkowa Kościoła obejmuje zatem także możliwość alienowania należących do niego dóbr doczesnych².

Alienacja (sensu stricto) w prawie kanonicznym to akt prawny, skutkujący przeniesieniem własności dóbr kościelnych na inny podmiot. Takie przeniesienie może nastąpić na podstawie różnego typu umów - zarówno odpłatnych (sprzedaż, zamiana), jak i nieodpłatnych

\footnotetext{
${ }^{1}$ Codex Iuris Canonici. Auctoritate Ioannis Paulus PP. II promulgatus. Kodeks Prawa Kanonicznego. Przekład polski zatwierdzony przez Konferencję Episkopatu, Pallottinum 1984.

${ }^{2}$ T. PAw Luk, Prawo kanoniczne według Kodeksu Jana Pawła II. Tom IV. Doczesne dobra Kościoła. Sankcje w Kościele. Procesy, Olsztyn 1990, s. 28.
} 
(darowizna) $^{3}$. Alienacja może zostać dokonana na rzecz innej kościelnej osoby prawnej (np. w przypadku alienacji dokonywanej przez parafię na rzecz innej parafii lub diecezji) lub „niekościelnego” podmiotu prawa (np. w przypadku alienacji dokonywanej przez parafię na rzecz gminy, spółki prawa handlowego czy osoby fizycznej) ${ }^{4}$. Do aktów alienacji zalicza się także inne (niż prowadzące do przeniesienia własności) czynności prawne, z którymi wiąże się lub może się wiązać pogorszenie sytuacji majątkowej kościelnej osoby prawnej (tzw. alienacja sensu largo $)^{5}$.

${ }^{3}$ T. Pawluk, Prawo..., s. 50; P. Kaleta, Komentarz do Kodeksu Prawa Kanonicznego. Tom IV/1. Księga V. Dobra doczesne Kościoła, red. Józef Krukowski, Poznań 2019, s. 102; Tenże, Kościelne prawo majątkowe, Lublin 2014, s. 206; Tenże, Prawne aspekty zarządzania dobrami kościelnymi, Lublin 2017, s, 208-209; A. DomaszK, Dobra doczesne Kościoła, Warszawa 2016, s. 247; Tenże, Zarządzanie dobrami doczesnymi parafii, Warszawa 2020, s. 290; L. Świto, Alienacja majątku kościelnego w diecezjach rzymskokatolickich w Polsce, Olsztyn 2010, s. 89; M. SitArz, Warunki alienacji majątku kościelnego według KPK/1983, Roczniki Nauk Prawnych 2000, t. X, z. 2, s. 96; W. ADAMCZEWsKi, Elementy prawa kanonicznego ze szczególnym uwzględnieniem kościelnej osoby prawnej w obrocie prawnym, Nowy Przegląd Notarialny 2007, nr 3, s. 15-16.

${ }^{4}$ A. Domaszk, Dobra..., s. 248; Tenże, Zarzadzanie..., s. 290-291.

${ }^{5}$ P. Kaleta (Komentarz..., s. 103) do aktów alienacji zalicza także: „użycie majątku stałego w innym celu niż był pierwotnie zgodnie z prawem przeznaczony; (...) jakikolwiek akt, w którym majątek kościelny podlega obciążeniom wieczystym lub długoterminowym, takim jak prawo użytkowania lub służebności; (...) sprzedaż rzeczy kosztownych lub przenoszenie na stałe relikwii i obrazów, które są uszanowane wielką czcią ludzi”. Tenże (Kościelne..., s. 205 oraz Prawne..., s. 204-205) prezentuje katalog czynności uznawanych w doktrynie prawa kanonicznego za akty alienacji. A. Domaszk (Dobra..., s. 247) do alienacji sensu largo zalicza: dzierżawę, zastaw, hipotekę, pożyczkę. L. Śwıto (Alienacja..., s. 90-91) wskazuje, że alienację sensu largo stanowią m.in. następujące czynności prawne: ustanowienie dzierżawy, najmu, zastawu, hipoteki, służebności gruntowej i osobistej, użytkowania, udzielenie poręczenia, użyczenia, pożyczki, jak również zrzeczenie się przysługującej kościelnej osobie prawnej służebności oraz zrzeczenie się sporu przez zawarcie ugody. Tenże (Alienacja..., s. 225-228) uznaje za alienację sensu largo zawarcie umowy o eurodotację. Podobne przykłady czynności podaje M. ToмкIEwicz, Obrót majątkiem Kościoła rzymskokatolickiego w Polsce, Olsztyn 2013, s. 45-46. M. Sitarz (Warunki..., s. 96) stwierdza, że „alienacją w pojęciu prawa kodeksowego 
Zgodnie z zasadą res Ecclesiae alienari non posse, dóbr kościelnych nie należy alienować ${ }^{6}$. Jednakże obowiązujące obecnie prawo kanoniczne nie zakazuje alienacji, przeciwnie - wskazuje, że jest ona wrodzonym prawem Kościoła (kan. $1254 \$ 1 \mathrm{KPK})^{7}$. Alienacja dóbr kościelnych jest jednak dopuszczalna pod warunkiem zaistnienia określonych okoliczności (w przypadku racjonalnego gospodarowania dobrami kościelnymi czy też zaistnienia szczególnych potrzeb) i spełnienia prawnych wymogów jej dokonania ${ }^{8}$.

nie jest (gdyż nie przynosi pogorszenia stanu posiadania): zaciągnięcie pożyczki bez obciążenia (np. bez hipoteki), korzystna lokata pieniędzy, spłata pożyczki lub kupno rzeczy za pieniądze będące w obrocie a nie ulokowane na stałe jako kapitał, sprzedaż papierów wartościowych, by wybudować potrzebny dom mieszkalny. Nie jest także alienacją utrata dóbr materialnych na skutek przemocy lub kradzieży. Czynności te, choć uszczuplają stan posiadania, nie przenoszą w sposób legalny praw własności. Podobne stanowisko zajmuje także P. KAleta, Zadania zarzadcy majątku kościelnego w Kodeksie Prawa Kanonicznego z 1983 roku i w polskich synodach diecezjalnych, Lublin 2012, s. 149. L. Świto, M. ToмкIEw ICz (Kompetencje Stolicy Apostolskiej w zakresie alienacji majątku powszechnego w świetle Kodeksu Prawa Kanonicznego z 1983 r., w: Pecunia servire debet sed non regere. Księga jubileuszowa dedykowana Księdzu Profesorowi Stanisławowi Dubielowi, red. K. Wiak, P. Kaleta, Lublin 2017, s. 398) wskazują, że „czynności alienacyjne sensu largo nie mają charakteru katalogu zamkniętego i należą do nich również wszelkie inne transakcje, w tym mające postać umów nienazwanych, z zawarciem których związane jest ryzyko pogorszenia sytuacji majątkowej Kościoła”. Genezę i znaczenie pojęcia alienacji sensu largo szerzej przedstawia P. Kaleta (Prawne..., s. 210-211).

${ }^{6}$ T. PAwluk (Prawo..., s. 50), uzasadniając zakaz alienacji dóbr kościelnych stwierdza, że „są one ściśle związane z realizacją misji Kościoła, a przez to zostały niejako wyłączone z użytku doczesnego i poświęcone Bogu”. Genezę zakazu alienacji dóbr kościelnych we wczesnym prawie kanonicznym przedstawia E. KowALCzYK (Zakaz alienacji dóbr kościelnych instytucji dobroczynnych w cesarstwie rzymskim, Prawo Kanoniczne 55 (2012) nr 2, s. 105-119).

${ }^{7}$ P. Kaleta, Komentarz..., s. 103; Tenże, Kościelne..., s. 207; A. Domaszk, Dobra..., s. 251.

${ }^{8}$ T. Pawluk, Prawo..., s. 50; A. Domaszk, Dobra..., s. 251-252; Tenże, Zarzadzanie..., s. 292. M. Sitarz (Warunki..., s. 97) stwierdza, że „prawo kanoniczne ustanawia kontrolę nad wszelkimi czynnościami tego rodzaju, dopuszcza je tylko z konieczności i przy zachowaniu przepisanych formalności”. M. ToMkIEwICz (Obrót..., s. 20) zauważa, że „prawodawca kościelny dopuszcza akty alienacji 
Najważniejszym wymogiem alienacyjnym jest zezwolenie na jej dokonanie ${ }^{9}$. Zgodnie z kan. 1291 KPK, dla dokonania ważnej alienacji dóbr stanowiących stały prawnie nabyty majątek publicznej osoby prawnej, których wartość przekracza określoną w prawie sumę, wymagane jest zezwolenie kompetentnej władzy, zgodnie z przepisami prawa. Kanoniczna ważność alienacji dóbr kościelnych, których wartość przekracza określoną kwotę uzależniona jest zatem od zezwolenia (zgody) kompetentnej władzy kościelnej ${ }^{10}$. Z powyższego przepisu wynika jednocześnie, że przewidziane w KPK wymogi alienacyjne dotyczą dóbr stanowiących stały majątek publicznej osoby prawnej ${ }^{11}$.

w odniesieniu do majątku kościelnego, wyraźnie jednak traktując je na zasadzie wyjątku od reguły. Będąc odstępstwem od zasady nienaruszalności mienia kościelnego, alienacja jest instytucją w założeniu swym ściśle reglamentowaną prawnie”. A. RzEPECKI (Funkcjonowanie prawa kanonicznego w polskim porzadku prawnym zarys tematu, Acta Erasmiana 2013, t. V, Varia, s. 181-182) stwierdza, że prawo kanoniczne „przyjmuje konstrukcję profilaktycznego systemu kontroli w odniesieniu do ważności alienacji dóbr kościelnych poprzez wprowadzenie instrumentu, który służy koordynacji działań dotyczących majątków podmiotów kościelnych. Chodzi tu o zezwolenie kompetentnej władzy, które wymagane jest do alienacji dóbr stanowiących część majątku stałego publicznej osoby prawnej, a których wartość przekracza ustanowioną przez prawo sumę".

${ }^{9}$ Kanoniczne wymogi alienacyjne w prawie powszechnym szczegółowo prezentują M. SitArz (Warunki..., s. 97-110), L. Świto (Alienacja..., s. 113-127) oraz P. KALETA (Kościelne..., s. 207-221). Wymogi alienacyjne w wybranym ustawodawstwie synodalnym prezentuje P. Kaleta (Zadania..., s. 149-153). Wymogi dotyczące zawarcia przez kościelną osobę prawną umowy dzierżawy nieruchomości prezentuje P. Kaleta (Zasady zawierania umowy dzierżawy w Kodeksie prawa kanonicznego z 1983 roku, Annales Canonici 2013, nr 9, s. 119-137).

${ }^{10}$ A. Domaszk (Dobra..., s. 252) zauważa, że „zgoda kompetentnej władzy gwarantuje rozważanie motywów alienacji w zakresie ich sprawiedliwości i rozumności. Jest to narzędzie kontroli i koordynacji działań dotyczących majątku kościelnego”. Procedurę uzyskiwania zgody na alienację szczegółowo prezentują L. Świto (Alienacja..., s. 127-138) oraz M. Toмkiewicz (Obrót..., s. 119-127).

${ }^{11}$ Wymogi te dotyczą również rzeczy darowanych Kościołowi na podstawie ślubu, rzeczy kosztownych z racji artystycznych lub historycznych (kan. $1292 \$ 2$ KPK) oraz relikwii i obrazów, które w jakimś kościele doznają wielkiej czci wiernych (kan. 1190 KPK). 
Majątek stały (patrimonium stabile) to „dobra, które nie są bezpośrednio przeznaczone na potrzeby życia codziennego i nie podlegają obrotowi, gdyż stanowią ogólną podstawę egzystencji i funkcjonowania osoby prawnej"12. Jest on „przeciwieństwem do wolnego lub płynnego kapitału, który ma zastosowanie w celu pokrycia bieżących wydatków"13. Tworzyć go mogą zarówno rzeczy (ruchomości i nieruchomości), jak również inne niż własność prawa majątkowe. W jego skład wchodzić mogą m.in. grunty i budynki, kosztowności (np. dzieła sztuki i inne dobra kultury), środki pieniężne w gotówce lub ulokowane na rachunkach i lokatach bankowych, papiery wartościowe (akcje lub obligacje) czy złoto ${ }^{14}$. O tym, czy dany składnik majątku wchodzi w skład patrimonium stabile decyduje jego prawne przeznaczenie $^{15}$ - „ma on stanowić bezpieczną podstawę finansowania kościelnej osoby prawnej, który ma umożliwić niezależne wypełnianie jej misji”'16.

${ }^{12}$ T. Pawluk, Prawo..., s. 50.

${ }^{13}$ P. Kaleta, Komentarz..., s. 102. Tenże (Pojęcie patrimonium stabile, Roczniki Nauk Prawnych 2014, t. XXIV, nr 4, s. 153) zauważa, że „majątek stanowiący patrimonium stabile nie jest przeznaczony na konsumpcje lub alienacje, ale na zachowanie majątku".

${ }^{14}$ T. Pawluk, Prawo..., s. 50; P. Kaleta, Komentarz..., s. 103; A. Domaszk, Dobra..., s. 252-253. Szersze rozważania dotyczące genezy i znaczenia pojęcia patrimonium stabile oraz jego składników prezentuje P. Kaleta (Pojęcie..., s. 147-161 oraz Kościelne..., s. 58-61), jak również L. Śwıтo (Alienacja..., s. 104-106) oraz M. Toмkiewicz (Obrót..., s. 21-24).

${ }^{15}$ T. Pawluk, Prawo..., s. 50; A. Domaszk, Dobra..., s. 253-254; Tenże, Zarzqdzanie..., s. 293; L. Świto, M. Toмkiewicz (Kompetencje..., s. 400) wskazują, że „o tym, co w odniesieniu do danego podmiotu stanowi jego patrimonium stabile (...) winien decydować nie tyle charakter mienia, lecz to, na ile owo mienie wpływa na stabilność sytuacji ekonomicznej danego podmiotu”. P. Kaleta (Prawne..., s. 203), powołując się treść kan. 1291 KPK, zwraca uwagę, że „patrimonium stabile kościelnej osoby prawnej powinno być zgodnie z prawem określone. Nie ma jednak prawnych zasad jego asygnacji, ponieważ zależy to nie tylko od natury i właściwości dóbr, lecz także od finansowych wymagań, aby kościelna osoba prawna mogła realizować cele, dla których została ustanowiona”.

${ }^{16}$ P. Kaleta, Komentarz..., s. 102. 
Zezwolenie kompetentnej władzy kościelnej jest wymagane dla alienacji dóbr o określonej wartości. Zgodnie z kan. $1292 \$ 1$ i 2 KPK, gdy wartość dóbr, których alienacja jest zamierzona, mieści się w ramach między najniższą i największą sumą, określoną dla własnego kraju przez Konferencję Episkopatu, kompetentną władzę, jeśli idzie o osoby prawne nie podlegające biskupowi diecezjalnemu, ustalają własne statuty. W innym razie kompetentną władzą jest biskup diecezjalny, za zgodą Rady do spraw ekonomicznych i kolegium konsultorów, jak również zainteresowanych osób. Ich także zgodę musi uzyskać biskup diecezjalny w wypadku alienacji dóbr diecezji. Jeżeli natomiast chodzi o rzeczy, których wartość przekracza najwyższą sumę, lub chodzi o rzeczy darowane Kościołowi na podstawie ślubu, a także o rzeczy kosztowne $\mathrm{z}$ racji artystycznych lub historycznych, do ważności alienacji potrzebne jest ponadto zezwolenie Stolicy Świętej. Kanon $1292 \$ 1$ KPK nakazuje jednocześnie zachowywać (stosować) przy alienacji kan. $638 \$ 3 \mathrm{KPK}$, zgodnie z którym do ważności alienacji i jakiegokolwiek działania, przez które stan majątkowy osoby prawnej może doznać uszczerbku, potrzebne jest pisemne zezwolenie kompetentnego przełożonego, wydane za zgodą jego rady. Jeśli natomiast chodzi o transakcje, w których suma przekracza wysokość określoną dla danego regionu przez Stolicę Apostolską, albo przedmiotem są dobra ofiarowane Kościołowi na mocy ślubu albo rzeczy drogocenne $\mathrm{z}$ racji artystycznych lub historycznych, potrzebna jest ponadto zgoda Stolicy Świętej ${ }^{17}$.

W przypadku, gdy wartość alienowanych dóbr nie przekracza sumy najniższej dla ważnego dokonania alienacji nie jest wymagane zezwolenie $^{18}$. W przypadku, gdy wartość alienowanych dóbr mieści

\footnotetext{
${ }^{17}$ Kwestie dotyczące relacji między regulacjami kan. $638 \$ 3$ i $1292 \$ 1$ KPK oraz pojawiające się na tym tle wątpliwości, dotyczące m.in. sposobu ustalania wartości alienacji prezentują L. Świto, M. Tomkiewicz (Kompetencje..., s. 400-402). Temat ten porusza również M. Томкiewicz (Obrót..., s. 125-126).

${ }^{18}$ Należy jednak zwrócić w tym miejscu uwagę na kan. 1295 i 1298 KPK, o których szerzej poniżej. P. KALETA (Komentarz..., s. 106) uznając, że również w takim przypadku może być konieczne uzyskanie zezwolenia na alienację, stwierdza, że „ustawodawca w kan. $1292 \$ 1$ in principio odwołał się do kan. $638 \$ 3$ (...). Należy
} 
się między sumą najniższą i sumą najwyższą, dla ważnego dokonania alienacji wymagane jest zezwolenie kompetentnej władzy (władzą tą jest biskup diecezjalny, który przed wydaniem zezwolenia na alienację musi uzyskać zgodę kolegialnych organów doradczych ${ }^{19}$, tj. rady do spraw ekonomicznych i kolegium konsultorów, jak również zainteresowanych osób ${ }^{20}$; zgodę tych podmiotów biskup diecezjalny musi uzyskać także w przypadku dokonywania alienacji dóbr należących do diecezji; natomiast w przypadku alienacji dokonywanej przez osoby prawne nie podlegające biskupowi diecezjalnemu, kompetentną do wydania zezwolenia władzę ustalają własne statuty tych

podkreślić, że przepis ten nie zawiera wzmianki o minimalnej sumie alienacji, lecz wskazuje na każdą alienację, do ważności której wymagane jest zezwolenie kompetentnej władzy”. L. Św Iтo (Alienacja..., s. 102) zauważa, że „akty alienacyjne w odniesieniu do majątku o wartości poniżej 100 tys. euro nie podlegają zatem procedurze określonej w przepisami szczególnymi Tytułu III, co nie oznacza jednakże, iż pozostają one poza jakąkolwiek regulacją i że kościelny majątek o wartości np. 99 tys. euro może być przez każdego zarządcę całkowicie dowolnie sprzedany lub darowany. Alienacja (...) zawsze pozostaje bowiem aktem wykraczającym poza zwykły zarząd i wówczas, gdy nie stosuje się doń trybu określonego w Tytule III, podlega reżimowi postępowania przewidzianemu w kan. 1277 i kan. 1281 \$ 1 KPK”. A. Domaszk (Dobra..., s. 259) wskazuje na możliwość zastrzeżenia konieczności uzyskania zezwolenia na taką alienację w prawie partykularnym, jak również na treść kan. 1281 KPK. Także W. AdA MCzewski (Elementy..., s. 16) zwraca uwagę na możliwość zastrzeżenia dodatkowych wymogów przez prawo partykularne lub prawo wewnętrzne (zakonne, statutowe).

${ }^{19}$ P. Kaleta (Komentarz..., s. 106) stwierdza, że „wymagana w prawie zgoda powinna być udzielona przez wszystkie organy konsultacyjne oraz zainteresowane osoby biorące udział w alienacji. Gdyby jedna z tych osób odmówiła zgody, akt byłby nieważny".

${ }^{20}$ A. Domaszk (Dobra..., s. 264) wskazuje, że „osobą zainteresowaną dokonaniem alienacji może być fundator, ofiarodawca, proboszcz, rektor kościoła, ewentualny posiadacz praw personalnych lub realnych, pełniący urząd, z którym związana jest administracja alienowanej rzeczy lub urząd, na który wpłynie dokonanie alienacji”. Podobny katalog osób podaje P. Kaleta (Kościelne..., s. 212). Na wątpliwości związane z ustaleniem znaczenia i zakresu pojęcia „osoba zainteresowana” uwagę zwracają L. Świto (Alienacja..., s. 117-118) oraz M. Toмkiewicz (Obrót..., s. 130). 
osób prawnych) ${ }^{21}$. W przypadku, gdy wartość alienowanych dóbr przekracza sumę najwyższą (a także w przypadku, gdy przedmiotem alienacji mają być rzeczy darowane Kościołowi na podstawie ślubu, a także o rzeczy kosztowne $\mathrm{z}$ racji artystycznych lub historycznych ${ }^{22}$ ) dla ważnego dokonania alienacji wymagane jest ponadto (a zatem łącznie z zezwoleniem biskupa diecezjalnego lub innej, wskazanej przez statuty władzy ${ }^{23}$ ) zezwolenie Stolicy Świętej ${ }^{24}$.

\footnotetext{
${ }^{21}$ Władzę kompetentną do wydania zezwolenia szczegółowo wskazuje P. KALETA (Kościelne..., s. 209) oraz M. Tomkiewicz (Obrót..., s. 103-104).

${ }^{22}$ Zgodnie z kan. $1190 \mathrm{KPK}$ : nie godzi się sprzedawać relikwii; relikwie znaczne
} i inne doznające wielkiej czci ze strony wiernych, nie mogą być w jakikolwiek sposób ważnie alienowane ani też na stałe przenoszone bez zezwolenia Stolicy Apostolskiej; obowiązuje to także w odniesieniu do obrazów, które w jakimś kościele doznają wielkiej czci wiernych. A. Domaszk (Dobra..., s. 263) podkreśla, że „wymagane zezwolenie Stolicy Apostolskiej w odniesieniu do rzeczy ofiarowanej z racji ślubu czy tych dóbr, które cechują się wyjątkowymi walorami historycznymi lub artystycznymi jest obowiązkowe, także gdy ich wartość nie przekracza najwyższej sumy”. L. Świto (Alienacja..., s. 107) stwierdza, że „bez względu na to, jaką wartość majątkową przedstawiałyby wymienione przedmioty, ich alienacja zawsze wymaga zgody również Stolicy Apostolskiej. Zgoda ta będzie zatem konieczna zarówno wtedy, gdy alienowana rzecz należąca do wymienionej kategorii dóbr ma wartość przekraczającą sumę $1 \mathrm{mln}$ euro, ale również i wówczas gdyby przedstawia niewielką, a nawet i żadną wartość materialną". Szczegółowe rozważania dotyczące zezwolenia Stolicy Świętej na alienację rzeczy darowanych Kościołowi na podstawie ślubu, a także o rzeczy kosztownych z racji artystycznych lub historycznych prezentują L. Świto, M. Tomkiewicz (Kompetencje..., s. 402-405).

${ }^{23}$ P. Kaleta (Komentarz..., s. 107) podkreśla, że „zezwolenie Stolicy Świętej jest kolejnym wymogiem do ważności aktu alienacji. Uzyskanie od niej zezwolenia nie zastępuje zgody biskupa diecezjalnego".

${ }^{24}$ Zezwolenie to wydaje Kongregacja ds. Duchowieństwa, a w przypadku alienacji dóbr instytutów życia konsekrowanego lub stowarzyszeń życia apostolskiego - Kongregacja ds. Instytutów Życia Konsekrowanego i Stowarzyszeń Życia Apostolskiego. Zezwolenie Stolicy Świętej może także zostać wydane przez legata papieskiego może to jednak nastąpić jedynie, gdy jest to konieczne (np. w związku z ryzykiem powstania szkody na skutek opóźnienia) oraz gdy wartość alienacji nie przekracza podwójnej wysokości sumy maksymalnej (Kongregacja DS. BIskupów, Index facultatum legatis pontificiis tributarum, 1986, nr 6, w: Ius Missionale 5(2011), s. 306-309). Kwestie dotyczące zezwolenia Stolicy Świętej na alienację majątku stałego 
Zasady alienacji dóbr należących do instytutów zakonnych określa kan. $638 \$ 3 \mathrm{KPK}$, natomiast przepisy właściwe dla alienacji dóbr instytutów świeckich wskazuje kan. $718 \mathrm{KPK}$, a stowarzyszeń życia apostolskiego - kan. $741 \$ 1 \mathrm{KPK}^{25}$.

Wysokość sumy najniższej i sumy najwyższej ustala Konferencję Episkopatu. W Polsce sumy te wynoszą obecnie: suma najniższa 100000 (sto tysięcy) euro, suma najwyższa - 1000000 (jeden milion) euro $^{26}$.

Stopniowej alienacji rzeczy podzielnych bez wymaganej zgody kompetentnej władzy (alienacji części określonej majątkowej całości²7, mogącej w rezultacie prowadzić do alienacji tej całości) zapobiega kan. $1292 \$ 3 \mathrm{KPK}^{28}$. Zgodnie z jego treścią, gdy rzecz alienowana jest

i innych dóbr oraz charakteru prawnego i formalnych wymogów takiego zezwolenia szczegółowo prezentują L. Świto, M. Tomkiewicz (Kompetencje..., s. 393-408).

${ }^{25}$ Tryb postępowania alienacyjnego w odniesieniu do majątków zakonnych, majątku instytutów świeckich i stowarzyszeń życia apostolskiego szczegółowo prezentuje M. Tomkiewicz (Obrót..., s. 107-119). Odrębne zasady dotyczące warunków ważnej alienacji w instytutach życia konsekrowanego i stowarzyszeniach życia apostolskiego prezentuje również P. KALETA (Akty alienacji i transakcji w instytutach $\dot{z} y c i a$ konsekrowanego i stowarzyszeniach życia apostolskiego, Prawo Kanoniczne 62 (2019) nr 4, s. 131-150).

${ }^{26}$ Wysokość sum ustaliła Konferencja Episkopatu Polski na 337. Zebraniu Plenarnym, obradującym w Warszawie w dniach 18-19 października 2006 r. Dekret Kongregacji ds. Biskupów (Prot. 901/84) zatwierdzający tę decyzję wszedł w życie 20 lutego 2007 r. (Akta Konferencji Episkopatu Polski 2007, nr 13, s. 32-33). Poprzednio obowiązuje w Polsce sumy wynosiły: suma najniższa - 100000 (sto tysięcy) USD, suma najwyższa - 500000 (pięćset tysięcy) USD. Zostały one ustalone na 227. Zebraniu Plenarnym, obradującym w Szczecinie w dniach 16-18 czerwca 1995 r. (Akta Konferencji Episkopatu Polski 1998, nr 1, s. 143-145). A. Domaszk (Zarządzanie..., s. 292) zauważa, że „w polskich warunkach najniższa suma (100 tys. euro) jest dużą kwotą. Wydaje się, że ta suma dla parafii powinna być niższa. Niewygórowany poziom dałby szerszy zakres kontroli ze strony biskupa diecezjalnego". Nota: Od 19.04.2021 kwota została podwyższona do 1700000 euro.

${ }^{27}$ Rzecz podzielną w rozumieniu tego przepisu mogą stanowić np. nieruchomości gruntowe, które mogą zostać podzielone czy budynki, z których można wyodrębnić lokale, ale także określone kolekcje dzieł sztuki, księgozbiory, itp.

${ }^{28}$ T. Pawluk, Prawo..., s. 51; M. Sitarz, Warunki..., s. 108-109; L. Świto, Alienacja..., s. 124; P. Kaleta, Komentarz..., s. 109; Tenże, Kościelne..., s. 217; 
podzielna, w prośbie o zezwolenie na alienację trzeba wyszczególnić części już wcześniej alienowane. W przeciwnym razie zezwolenie jest nieważne ${ }^{29}$.

Kan. $1292 \S 4$ KPK nakłada na osoby wyrażające opinię lub zgodę na dokonanie alienacji obowiązek dochowania szczególnej staranności w zakresie zapoznania się ze stanem majątkowym podmiotu dokonującego alienacji ${ }^{30}$. Przepis ten wskazuje, że ci, którzy winni mieć udział w alienowaniu dóbr przez wyrażenie zdania lub zgody, nie powinni wyrażać zdania lub zgody, dopóki nie zapoznają się dokładnie ze stanem materialnym osoby prawnej, której dobra maja być alienowane, jak również z alienacjami już dokonanymi.

Konieczność uzyskania zezwolenia kompetentnej władzy jest kanonicznym warunkiem ważności alienacji ${ }^{31}$. Kościelne prawo majątkowe przewiduje jednak także dodatkowe wymogi alienacyjne od których uzależniona jest nie ważność, a godziwość alienacji32.

Zgodnie z kan. 1293 KPK, dla dokonania alienacji, której wartość przekracza najniższą określoną sumę, wymaga się ponadto słusznej

A. Domaszk, Dobra..., s. 264; Tenże, Zarzadzanie..., s. 300; M. Toмкiewicz, Obrót..., s. 42-43; W. AdAMCZEWski, Elementy.., s. 18.

${ }^{29}$ P. Kaleta (Kościelne..., s. 216) wskazuje, że „przepis ten może mieć również zastosowanie do alienacji przeprowadzonej równocześnie w odniesieniu do wielu różnych dóbr (zatajenie tego faktu obwarowane jest nieważności aktu)". Na kwestię tę zwraca także uwagę A. Domaszk (Dobra..., s. 264-265) oraz M. TomkiEwicz (Obrót..., s. 43).

${ }^{30}$ Szerzej obowiązki tych osób przedstawiają P. KALETA (Komentarz..., s. 110) oraz A. Domaszk (Dobra..., s. 265).

${ }^{31}$ Tryb postępowania alienacyjnego oraz procedurę uzyskiwania zezwolenia na alienację kompetentnej władzy kościelnej szczegółowo prezentują L. Świto (Alienacja..., s. 127-138) oraz M. ToмкiEwicz (Obrót..., s. 102-127).

${ }^{32}$ T. PAwluk (Prawo..., s. 51-52) stwierdza, że „zarówno słuszna przyczyna, jak i ocena rzeczy alienowanej przez rzeczoznawców nie są wymagane do ważności aktu alienacji, jak zezwolenie właściwej władzy, lecz tylko do tego, aby alienacja była dozwolona, czyli godziwa”. Także P. Kaleta (Komentarz..., s. 111) stwierdza, że „wymagania przedstawione w kan. 1293 nie dotyczą ważności aktu alienacji, lecz jego godziwości”. Takie stanowisko prezentuje również A. Domaszk (Dobra..., s. 266). 
przyczyny ${ }^{33}$, jak nagląca potrzeba, wyraźna korzyść, pobożność, miłość lub inna poważna racja pasterska oraz oceny rzeczy alienowanej, dokonanej na piśmie przez rzeczoznawców ${ }^{34}$. Należy ponadto zachować inne środki ostrożności ${ }^{35}$ przepisane przez kompetentną władzę, aby uniknąć szkody Kościoła.

${ }^{33}$ T. PAwluk (Prawo..., s. 51) wskazuje, że wymaganą do alienacji słuszną przyczyną może być m.in. przeprowadzenie remontu kościoła, zakup sprzętów liturgicznych, spłata długów, sprzedaż zbędnych rzeczy, potrzeba budowy obiektu sakralnego lub domu parafialnego oraz pomoc ubogim w czasie wojny lub inne klęski. Podobne przykłady podają P. Kaleta (Komentarz..., s. 111 oraz Kościelne..., s. 219-220), A. Domaszk (Dobra..., s. 266-267 oraz Zarządzanie..., s. 294), L. Świto (Alienacja..., 124-125) oraz M. Toмкiewicz (Obrót..., s. 36-37).

${ }^{34}$ P. Kaleta (Komentarz..., s. 111) zauważa, że „wycena rzeczy alienowanej ma być dokonana przez przynajmniej dwóch rzeczoznawców na piśmie. Rzeczoznawcy powinni być niezależni od siebie. (...) Wycena rzeczy alienowanej powinna być sporządzona według wartości rynkowej”. Tak również A. Domaszk (Dobra..., s. 267), który stwierdza również, że wartość alienowanego dobra „powinni wskazać biegli. Tym samym nie jest tu wiążącym punktem odniesienia suma proponowana przez oferentów czy ewentualnych nabywców”.

${ }^{35}$ T. PAwLuk (Prawo..., s. 52) stwierdza, że wskazane w kan. $1293 \$ 2$ KPK środki ostrożności „mają na celu zabezpieczenie przed możliwymi stratami”. Jednocześnie przykładowo wskazuje, że środki te mogą polegać na publicznej zapowiedzi alienacji czy dokonywaniu alienacji raczej poprzez zamianę (ze względu na możliwość zmiany wartość pieniądza). Takie stanowisko prezentuje także M. SITARz (Warunki..., s. 110). P. KALETA (Komentarz..., s. 112) zalicza do środków ostrożności: powiadomienie o alienacji ordynariusza miejsca, przeprowadzenie alienacji w drodze przetargu publicznego, uzyskanie na alienację zgody rady do spraw ekonomicznych oraz przestrzeganie prawa świeckiego (jeżeli kontrahentem jest cywilna osoba prawna). A. Domaszk (Dobra..., s. 268 oraz Zarządzanie..., s. 303) wskazuje ponadto na możliwość określenia przymiotów nabywcy, poręczenie zapłaty ceny, klauzulę stabilizacji pieniądza, wskazanie w umowie alienacyjnej konieczności przestrzegania nie tylko prawa cywilnego, ale kanonicznego czy wykluczenie istnienia prawa pierwokupu zbywanej nieruchomości lub innych ograniczeń w jej rozporządzaniu. L. Świto (Alienacja..., s. 125-126) zauważa natomiast, że „aktualnie prawo kanoniczne nie wymaga już (...) by sprzedaż rzeczy miała być dokonywana przy zastosowaniu przetargu publicznego lub by należało ją publicznie zapowiedzieć. Rzecz alienowana nie musi też być przyznawana temu, kto więcej oferuje”. 
Dodatkowe wymogi alienacyjne (do godziwości tego aktu ${ }^{36}$ ) wskazuje kan. $1294 \mathrm{KPK}$. Zgodnie z jego treścią, z reguły nie powinno się alienować rzeczy za niższą sumę od określonej w ocenie ${ }^{37}$, natomiast pieniądze uzyskane $\mathrm{z}$ alienacji należy bezpiecznie ulokować na korzyść Kościoła lub roztropnie je rozchodować, zgodnie z celami alienacji ${ }^{38}$.

Trzeba w tym miejscu wskazać także na treść kan. 1298 KPK, zgodnie z którym, jeśli nie chodzi o rzecz o bardzo małej wartości, nie wolno bez specjalnego pisemnego zezwolenia kompetentnej władzy sprzedawać lub wydzierżawiać dóbr kościelnych ich zarządcom albo krewnym lub powinowatym zarządców, aż do czwartego stopnia ${ }^{39}$. Przepis ten wprowadza szczególny wymóg alienacyjny (dotyczący także znacznej części dóbr, których wartość nie przekracza sumy najniższej ${ }^{40}$ ) - konieczność uzyskania zezwolenia kompetentnej władzy w przypadku dokonywania alienacji na rzecz zarządców

${ }^{36}$ P. Kaleta (Komentarz..., s. 112).
${ }^{37}$ P. Kaleta (Komentarz..., s. 112) zauważa, że „sformułowanie ‘z reguły' wskazuje na możliwość odstąpienia od zakazu alienacji, za cenę niższą niż określono w przygotowanej wycenie przez rzeczoznawców. Wynikać to może z różnych okoliczności, np. brak znalezienia nabywcy według ceny rynkowej, nabywcą rzeczy jest kościelna osoba prawna prowadząca cele charytatywne. Chcąc dokonać alienacji za cenę niższą niż w wycenie, wymagane jest zezwolenie kompetentnej władzy kościelnej”. A. Domaszk (Dobra..., s. 269) wskazuje na możliwość alienacji za cenę niższą w przypadku alienacji, „która ma miejsce pomiędzy dwoma parafiami tego samego Kościoła partykularnego. Wówczas względy eklezjalne przeważają nad interesem pojedynczej osoby prawnej".

${ }^{38}$ Szerzej na ten temat m.in. A. Domaszk (Dobra..., s. 269-270).

${ }^{39}$ A. DomAszk (Dobra..., s. 281) zauważa, że „norma kan. 1298 usuwa podejrzenia o bezprawne wzbogacenie się dzięki dobrom kościelnym i powiązaniom rodzinnym jednocześnie, czyli wyklucza ewentualny nepotyzm”.

${ }^{40}$ T. PAWluk (Prawo..., s. 53) stwierdza, że „rzecz małej wagi (...) nie musi pokrywać się z rzeczą, której wartość nie przekracza tzw. sumy najniższej”. A. Domaszk (Dobra..., s. 282) stwierdza, że „na pewno nie mogą to być dobra, których wartość przekracza kwotę minimalną, wskazaną przez Konferencję Episkopatu. Zwyczajnie nie są to wielkie wartości, niektórzy wskazują na sumy poniżej dziesiątej części kwoty minimalnej". 
alienowanego majątku albo ich krewnych lub powinowatych, aż do czwartego stopnia ${ }^{41}$.

Od aktów alienacji (sensu stricto) należy odróżnić transakcje (czynności prawne ${ }^{42}$ ), przez które stan majątkowy kościelnej osoby prawnej może ulec pogorszeniu ${ }^{43}$. Zgodnie jednak z kan. 1295 KPK, wymogi według kan. 1291-1294, do których też winny być dostosowane statuty osób prawnych, mają być zachowane nie tylko przy alienacji, ale również przy podejmowaniu jakiejkolwiek transakcji, na skutek której majątek osoby prawnej może się znaleźć w gorszej sytuacji ${ }^{44}$.

${ }^{41}$ Treść kan. 1298 KPK nie określa charakteru wskazanego w nim wymogu alienacyjnego. T. PAwluk (Prawo..., s. 53) zauważa, że „wydaje się, że specjalne zezwolenie na piśmie nie jest wymagane do ważności, lecz tylko godziwości umowy. Zezwolenie to jest specjalne, gdyż różni się od zezwolenia wymaganego do ważności na podstawie przepisu kan. 1291". Takie stanowisko prezentuje także P. KALETA (Komentarz..., s. 119) oraz A. Domaszk (Dobra..., s. 281). Również L. Świto (Alienacja..., s. 127) oraz M. ToмкiEwicz (Obrót..., s. 39) wskazują, że konieczność uzyskania przedmiotowego zezwolenia nie jest wymogiem ważności, a jedynie godziwości takiego aktu.

${ }^{42}$ P. Kaleta (Komentarz..., s. 113 oraz Prawne.., s. 212) zwraca uwagę, że użyte w kan. 1295 KPK stwierdzenie „transakcje” (łac. negotio) w istocie oznacza „czynności prawne”, które mogą pogorszyć stan majątkowy kościelnej osoby prawnej.

${ }^{43}$ P. Kaleta, Kościelne..., s. 222-223. Szczegółowe rozważania dotyczące tych transakcji prezentuje P. KALETA (Transakcje, które moga pogorszyć stan majątkowy kościelnej osoby prawnej (kan. 1295), Studia Prawnicze KUL 2016, nr 2, s. 63-80).

${ }^{44}$ T. PAwluk (Prawo..., s. 52) zalicza do takich czynności np. zrzeczenie się określonych uprawnień majątkowych, zawarcie ugody, dokonanie poręczenia majątkiem kościelnym, podjęcie sprawy, łączącej z ryzykiem utraty dóbr. P. Kaleta (Komentarz..., s. 115 oraz Kościelne..., s. 224-226) wskazuje m.in. następujące przykłady czynności prawnych, mogących pogorszyć stan majątkowy kościelnej osoby prawnej: zaciągnięcie pożyczki, ustanowienie hipoteki lub służebności gruntowej, zrzeczenie się służebności, zaciągnięcie kredytu pod zastaw rzeczy kosztownych, udzielenie poręczenia lub gwarancji, zawarcie długoterminowej umowy dzierżawy lub najmu, sprzedaż rzeczy, której wartość nie przekracza sumy minimalnej, podejmowanie inwestycji finansowanych z projektów unijnych, podejmowanie wspólnych przedsięwzięć ( join venture), powiernictwo dóbr kościelnych instytucji świeckiej oraz inwestycje w instrumenty rynku kapitałowego. Podobne przykłady podaje także A. Domaszk (Dobra..., s. 271) oraz L. Świto (Akty zarzqdu dobrami kościelnymi, Prawo Kanoniczne 58 (2015) nr 3, s. 112-113). 
Do transakcji tych stosuje się zatem zasady dotyczące dokonywania alienacji (wymogi dotyczące ważności i godziwości). Podobieństwo tych transakcji do alienacji, polegające na możliwości doprowadzenia do pogorszenia stanu majątkowego kościelnej osoby prawnej, powoduje, że czynności te zaliczane są do tzw. alienacji sensu $\operatorname{largo} o^{45}$.

\section{Kanonizacja przepisów prawa cywilnego dotyczących umów i zobowiązań}

Zgodnie z kan. 1290 KPK, to, co prawo państwowe na danym terytorium postanawia odnośnie do umów, zarówno w ogólności, jak i w szczególności, oraz do zobowiązań, ma być zachowywane również mocą prawa kanonicznego w odniesieniu do rzeczy podlegających władzy rządzenia Kościoła, z tymi samymi skutkami, chyba że są przeciwne prawu Bożemu lub co innego zastrzega prawo kanoniczne, i przy zachowaniu przepisu kan. $1547 \mathrm{KPK}^{46}$.

Na podstawie tego przepisu następuje tzw. kanonizacja prawa cywilnego (prawa świeckiego) ${ }^{47}$. Kanonizacja ta dotyczy wybranych przepisów prawa cywilnego ${ }^{48}$, dotyczących umów (kontraktów) oraz

${ }^{45}$ A. Domaszk, Dobra..., s. 270-271; M. Sitarz, Warunki..., s. 96; L. Świto, Alienacja..., s. 90; M. Tomkiewicz, Obrót..., s. 20; W. Adamczewski, Elementy..., s. 16. Przeciwko uznaniu takich transakcji za alienację sensu largo wypowiada się P. Kaleta (Komentarz..., s. 114-115 oraz Prawne..., s. 212-213).

${ }^{46}$ Kan. 1290 KPK nawiązuje do kan. 22 KPK, zgodnie z którym ustawy państwowe, do których odsyła prawo kościelne, należy zachować w prawie kanonicznym na ile nie są przeciwne prawu Bożemu i o ile prawo kanoniczne czego innego nie zastrzega.

${ }^{47}$ R. SobAŃski (Prawo kanoniczne a krajowy porządek prawny, Państwo i Prawo 1999, z. 6, s. 10) wskazuje, że „obecnie obowiązujący kodeks prawa kanonicznego w oryginale łacińskim nie zna terminu prawo świeckie, państwowe czy krajowe, lecz zachowuje dawne nazewnictwo: ius civile, podciągając pod tą nazwę wszystkie obowiązujące na terytorium danego państwa normy prawne, niezależnie od ich źródła”.

${ }^{48}$ Zakres i skutki kanonizacji prawa cywilnego szerzej omawia B. RAKoczY (Umowy w Kodeksie Prawa Kanonicznego w świetle kan. 1290, Studia z Prawa Wyznaniowego 2009, t. 12, s. 57-70). Tenże (Umowy..., s. 57) zauważa, że „nie jest (...) właściwe rozumienie ius civile w kan. 1290 KPK jako całokształtu prawa państwowego, a konkretnie prawa polskiego. Pojęcie to w kan. 1290 KPK użyte zostało na 
zobowiązań (stosunków cywilnoprawnych o charakterze względnym, powstających w wyniku zawarcia umowy, ale także w następstwie innych zdarzeń prawnych, jak np. wyrządzenie szkody czy bezpodstawne wzbogacenie $)^{49}$.

Kanonizację można uznać za szczególny rodzaj regulacji (techniki ${ }^{50}$ ) prawnej, opierającej się na zasadzie pomocniczości (subsydiarności). Kanonizacja polega na odwołaniu się przez prawodawcę kościelnego do określonych pozakościelnych norm prawnych i nakazaniu ich stosowania (zachowywania) w prawie kanonicznym ${ }^{51}$. W jej

oznaczenie prawa cywilnego jako gałęzi prawa państwowego, a nie na oznaczenie państwowego porządku prawnego".

${ }^{49}$ P. Kaleta (Komentarz..., s. 99-100) stwierdza, że „ustawodawca w kan. 1290 zastosował łaciński termin solutio, który dosłownie oznacza spełnienie świadczenia pieniężnego. Na tej podstawie należy uznać, że ustawodawca ma na uwadze zobowiązania pieniężne, które mogą pochodzić, np. z zawartej umowy o kredyt”.

${ }^{50}$ H. Jagodziński (Kanonizacja prawa cywilnego, Kieleckie Studia Teologiczne 2004, nr 3, s. 355) wskazuje, że kanonizacja prawa cywilnego to „technika prawna w prawie kanonicznym odsyłania do norm prawa cywilnego promulgowanych przez innego prawodawcę niż prawodawca kościelny".

${ }^{51}$ T. Pawluk, Prawo..., s. 49; M. Sitarz, Warunki..., s. 98. H. Jagodziński (Kanonizacja..., s. 355-356) zauważa, że kanonizacja prawa cywilnego „ma miejsce wtedy, gdy prawo kanoniczne zamiast uregulować pewną materię będącą w jego kompetencji, nakazuje zastosowanie częściowe lub całościowe norm prawa cywilnego. Normy prawa cywilnego, które materialnie, jak również w swojej treści należą do innego porządku prawnego, formalnie stają się własnymi normami prawa kościelnego, które nadaje im wartość prawa wewnętrznego dla swoich wiernych". S. Dubiel (Uprawnienia majątkowe Kościoła katolickiego w Polsce w świetle Kodeksu Prawa Kanonicznego z 1983 roku, Konkordatu z 1993 roku i ustaw synodalnych, Lublin 2007, s. 165) zauważa, że kanonizacja prawa cywilnego „ma długą tradycję w Kościele i polega na zdecydowaniu, które normy prawne danego państwa odnoszą się do społeczności religijnej”. A. Domaszk (Dobra..., s. 246) stwierdza, że „Kościół jest obecny w prawie wszystkich krajach świata, co oznacza złożoność i różnorodność rozwiązań prawnych. Z tego powodu ustawodawca kościelny nie stanowi własnego prawa nt. umów cywilno-prawnych, ale zasadniczo odsyła do ustawodawstwa państwowego w tej przestrzeni”. Szersze rozważania o kanonizacji prawa świeckiego prezentuje R. SoBAŃsKI (Kanonizacja prawa cywilnego w Kodeksie Prawa Kanonicznego, Studia Iuridica 1994, t. XXI, s. 305-311). 
wyniku prawo kanoniczne „uznaje niejako za swoje” 52 normy mające swe źródło w innym systemie prawnym ${ }^{53}$. Kanonizacja wybranych przepisów prawa cywilnego pozwala uniknąć sprzeczności pomiędzy prawem kościelnym i państwowym ${ }^{54}$ oraz zapewnia umowom i innym czynnościom kościelnych osób prawnych cywilnoprawną skuteczność na forum świeckim ${ }^{55}$. To swoiste powiązanie kanonicznego i świeckiego porządku prawnego można również uznać za wyraz dążenia Kościoła do pełniejszej relacji i współpracy z państwem ${ }^{56}$.

Skutkiem dokonanej w kan. 1290 KPK kanonizacji przepisów prawa świeckiego dotyczących umów i zobowiązań jest konieczność podporządkowania się im również na forum kościelnym (w odniesieniu do rzeczy podlegających władzy rządzenia Kościoła). Przedmiotowa

${ }^{52}$ T. Pawluk, Prawo..., s. 49; M. Sitarz, Warunki..., s. 98. R. Sobański (Prawo..., s. 10) zauważa, że „kanonizacja norm prawa świeckiego oznacza, że Kościół rezygnuje z własnej regulacji prawnej odnośnej materii oraz uznaje normy świeckie za odpowiadające i wystarczające na forum kościelnym. (...) Kanonizacja taka dowodzi generalnej afirmacji prawa świeckiego przez Kościół”.

${ }^{53}$ H. JAGodziński (Kanonizacja..., s. 356), zwraca uwagę, że „stąd również wydaje się być nieodzownym dla kanonisty zapoznanie się nie tylko z konkretnymi normami, ale również z kulturą prawną, jak i zasadami, którymi kieruje się porządek prawny w konkretnym kraju”. Tenże (Kanonizacja..., s. 364) zauważa także, że „prawodawstwo kościelne, odwołując się niekiedy do prawodawstwa cywilnego za pośrednictwem instytucji kanonizacji prawa cywilnego, pragnie przez nią otworzyć się na wymagania różnych narodów, jak i na różne okoliczności miejsca i czasu, aby tym lepiej przystosować się do lokalnych warunków".

${ }^{54}$ H. Jagodziński, Kanonizacja..., s. 356; S. Dubiel, Uprawnienia..., s. 165. A. DoMAszK (Dobra..., s. 249) stwierdza, że „kanonizacja ustaw cywilnych wynika z racji praktycznych, jak również zapobiega ewentualnym konfliktom prawnym. Ustanowienie szczegółowych norm kanonicznych w tym zakresie byłoby niekompatybilne z ustawodawstwem poszczególnych państw".

${ }^{55}$ P. Kaleta (Kościelne..., s. 208) stwierdza, że poprzez kanonizację prawa cywilnego „zostaje zagwarantowana pewność obrotu, zarówno w prawie kanonicznym, jak i cywilnym".

${ }^{56} \mathrm{Na}$ kwestię tę zwracają uwagę H. JAGodzIŃsKi (Kanonizacja..., s. 356) oraz S. Dubiel (Uprawnienia..., s. 165). 
kanonizacja nie jest jednak bezwzględna ${ }^{57}$. Kan. 1290 KPK zastrzega, że nie obejmuje ona przepisów prawa świeckiego, które są przeciwne prawu Bożemu oraz tych, w stosunku do których prawo kanoniczne przewidziało odmienną regulację prawną (za przykład można tu wskazać właśnie przepisy prawa kanonicznego dotyczące wymogów alienacji dóbr kościelnych) ${ }^{58}$. Jednocześnie prawodawca kościelny ogranicza dokonaną kanonizację prawa cywilnego, nakazując zachowywać przepis kan. $1547 \mathrm{KPK}^{59}$.

W wyniku dokonanej przez prawodawcę kościelnego kanonizacji przepisów prawa cywilnego dotyczących umów i zobowiązań, przepisy te znajdują zastosowanie do dokonywanej przez kościelne osoby prawne alienacji dóbr kościelnych oraz innych czynności, przez które stan majątkowy tych osób może ulec pogorszeniu ${ }^{60}$. Ocena ważności i skuteczności alienacji oraz innych transakcji na forum kościelnym powinna zatem uwzględniać również regulacje wynikające z polskiego prawa cywilnego ${ }^{61}$.

${ }^{57}$ P. Kaleta, Kościelne..., s. 208. H. Jagodziński (Kanonizacja..., s. 358) podkreśla, że „należy zauważyć, że Kościół nakazując zastosowanie prawa państwowego w konkretnej materii, nie zamierza w żadnym wypadku pozbawić siebie samego władzy uregulowania tejże materii w sposób autonomiczny. Kościół może więc przyjąć lub odrzucić w sposób swobodny przepisy mówiące o kanonizacji prawa cywilnego".

${ }^{58}$ T. Pawluk, Prawo..., s. 49; P. Kaleta, Komentarz..., s. 100-101; A. Domaszk, Dobra..., s. 250; S. Dubiel, Uprawnienia..., s. 166.

${ }^{59}$ Zgodnie z kan. 1547 KPK, dowód ze świadków dopuszcza się we wszystkich sprawach, pod kierownictwem sędziego.

${ }^{60}$ A. Domaszk, Zarzadzanie..., s. 291-292. P. Kaleta (Prawne..., s. 218) podkreśla, że „kościelna osoba prawna kiedy dokonuje transakcji z cywilnymi osobami prawnymi, zobowiązana jest zachować dwa porządki prawne: porządek prawa kanonicznego i państwowego”. L. Świto (Alienacja..., s. 114) wskazuje, że „w zakresie alienacji mających miejsce na obszarze Rzeczypospolitej Polskiej prawo kanoniczne przejęło jako własny polski porządek prawny, a co za tym idzie określone w prawie cywilny reguły dotyczące przedmiotu, formy, klauzul, warunków, opłat, itp. czy też odnośnie ważności zobowiązań i działań prawnych”.

${ }^{61}$ M. Sitarz (Warunki..., s. 98), P. Kaleta (Kościelne..., s. 208-209), L. Świto (Alienacja..., s. 113-114) oraz M. Toмkiewicz (Obrót..., s. 40) zaliczają zachowanie 
Warto w tym miejscu zwrócić także uwagę na konieczność przestrzegania prawa państwowego przez zarządców dóbr kościelnych ${ }^{62}$. Zgodnie z kan. $1284 \$ 2$ pkt $3 \mathrm{KPK}$, zarządcy dóbr kościelnych powinni przestrzegać przepisów zarówno prawa kanonicznego, jak i państwowego, albo wydanych przez fundatora, ofiarodawcę lub uprawnioną władzę, a zwłaszcza starać się, by Kościół nie poniósł szkody wskutek nieprzestrzegania ustaw państwowych.

\section{Kanoniczne skutki alienacji dokonanej bez dochowania prawnych wymogów}

Kościelne prawo majątkowe przewiduje dwa rodzaje wymogów alienacyjnych - zastrzeżone do ważności (kan.1291 i 1292 KPK) oraz godziwości (kan. 1293 i 1294 KPK) alienacji. Nie dochowanie tych wymogów wiąże się zatem z nieważnością bądź niegodziwością takiego aktu.

Nieważną na gruncie prawa kanonicznego jest alienacja dokonana bez zachowania kanonizowanych przepisów prawa cywilnego, alienacja dokonana bez wymaganego zezwolenia kompetentnej władzy kościelnej (lub z takim zezwoleniem ${ }^{63}$, wydanym jednak bez zgody rady do spraw ekonomicznych i kolegium konsultorów oraz zainteresowanych osób, jak również bez wcześniejszego zapoznania się przez osoby wyrażające opinię lub zgodę na dokonanie alienacji ze stanem materialnym osoby prawnej, której dobra mają być alienowane

postanowień (wymogów) prawa państwowego do kanonicznych warunków ważność alienacji.

${ }^{62}$ P. Kaleta, Komentarz..., s. 101; Tenże, Kościelne..., s. 226.

${ }^{63}$ M. Sitarz (Warunki..., s. 111) stwierdza, że „pominięcie formalności alienacyjnych przejawia się w zignorowaniu warunków dopuszczalności alienacji lub też w dokonaniu aktu bez uzyskania potrzebnych zezwoleń”. L. Śwıтo (Alienacja..., s. 120) zauważa, że „w przypadku alienacji dokonywanej przez zarządcę publicznej osoby prawnej podlegającej władzy biskupa, alienacja ta będzie nieważna zarówno wtedy, jeśli zarządca dokona jej bez zwrócenia się o zgodę do biskupa lub wbrew jego woli, jak również i wtedy jeśli biskup takiego zezwolenia udzieli bez zgody Rady ekonomicznej i kolegium konsultorów oraz zainteresowanych osób, gdy takie w sprawie występują". 
i z alienacjami już przez nią dokonanymi) oraz alienacja dokonana bez wykazania poprzednio dokonanych częściowych alienacji ${ }^{64}$.

Alienacją kanonicznie ważną, lecz niegodziwą ${ }^{65}$ jest alienacja dokonana bez istnienia słusznej przyczyny, alienacja dokonana bez wcześniejszej oceny (wyceny) rzeczy alienowanej przez rzeczoznawców $^{66}$, alienacja dokonana bez zachowania innych przewidzianych prawem środków ostrożności, alienacja za sumę niższą od określonej w ocenie rzeczoznawców oraz alienacja, z której uzyskane środki nie zostały bezpiecznie ulokowane na korzyść Kościoła lub roztropnie rozdysponowane, zgodnie z celami alienacji. Za ważną, lecz niegodziwą uznaje się także sprzedaż lub wydzierżawienie dóbr kościelnych (chyba, że o bardzo małej wartości), bez specjalnego pisemnego zezwolenia kompetentnej władzy, ich zarządcom albo ich krewnym lub powinowatym, aż do czwartego stopnia.

W przypadku dokonania alienacji bez dochowania kanonicznych wymogów walidacyjnych, alienacja taka będzie nieważna i nie będzie

${ }^{64}$ A. Domaszk (Dobra..., 276) zwraca uwagę, że może także chodzić „o ważność kanonicznego aktu prawnego albo możliwość jego unieważnienia wynikającą z: zewnętrznego przymusu, ciężkiej i nieusprawiedliwionej bojaźni, podstępu ignorancji lub błędu dotyczącego samej istoty aktu albo warunku wymaganego w sposób bezwzględny”. Zgodnie z kan. $124 \$ 1 \mathrm{KPK}$, do ważności aktu prawnego wymaga się, by był on dokonany przez zdolną do tego osobę oraz by były w nim zawarte wszystkie jego istotne elementy konstytutywne i zostały wypełnione formalności oraz warunki wymagane przez prawo do ważności aktu.

${ }^{65}$ M. Tomkiewicz (Obrót..., 35) zauważa, że „naruszenie warunków godziwości powoduje, iż alienacja jest niegodziwa, jednakże (...) taka czynność alienacyjna choć niegodziwa, będzie kanonicznie ważna”. P. Kaleta (Kościelne..., s. 219) wskazuje, że „niegodziwość aktu jest obwarowana sankcją nielegalności aktu, a udowodniona nielegalność aktu może być podstawą do dochodzenia zmiany aktu lub odszkodowania".

${ }^{66}$ A. Domaszk (Dobra..., 276) zauważa, że „choć opinię dotyczącą wartości dóbr alienowanych postrzega się w kontekście godziwości, to jednak wycena wskazuje na właściwy podmiot, który jest władny udzielić zgody. W konsekwencji brak takiej opinii mógłby spowodować, że zgody udzieliłby podmiot nieuprawniony”. M. SITARz (Warunki..., s. 99) zauważa, że „określenie, jakiej sumy dotyczy planowana alienacja, jest ważne, ponieważ władza udzielająca zezwolenia może być rożna w zależności od wartości rzeczy alienowanej”. 
wywoływać skutków prawnych na forum kościelnym. Możliwa jest jednak sanacja takiego aktu ${ }^{67}$. Jej dokonanie uzależnione jest jednak od woli władzy kościelnej, kompetentnej do wydania zezwolenia na alienację.

Zgodnie z kan. 1296 KPK, w razie alienacji dóbr kościelnych, dokonanej wprawdzie bez zachowania formalności przepisanych prawem kościelnym, lecz ważnej w świetle prawa państwowego, do kompetentnej władzy kościelnej należy decyzja, po dokładnym rozważeniu wszystkiego, czy i jaką skargę, mianowicie osobową lub rzeczową ${ }^{68}$, przez kogo i przeciw komu, należy wnieść dla odzyskania praw Kościoła. Przepis ten jest podstawą ewentualnych działań (skarg i roszczeń), które kościelna osoba prawna może podjąć w celu odzyskania bezprawnie alienowanych dóbr ${ }^{69}$.

Treść kan. 1296 KPK zwraca jednocześnie uwagę na możliwość zaistnienia sytuacji, w której kanonicznie nieważna (z powodu nie dochowania przy jej dokonywaniu wymogów kościelnych) alienacja

${ }^{67}$ T. Pawluk, Prawo..., s. 53; P. Kaleta, Komentarz..., s. 116; L. Świto, Alienacja..., s. 144. M. Toмkiewicz (Obrót..., s. 40) wskazuje, że „dokonanie czynności alienacyjnej z naruszeniem wskazanych wymogów czyni alienację taką nieważną w porządku prawa kanonicznego ipso iure. Nie zawsze jednakże nieważność alienacji jest nieważnością definitywną. Zgodnie bowiem z poglądem powszechnie przyjętym w doktrynie, nawet nieważna czynność alienacyjna może być sanowana przez kompetentną władzę kościelną". M. Sitarz (Warunki..., s. 111) zauważa, że „jeśli miały miejsce tylko niedociągnięcia formalne przy korzystnej czy nawet tylko nieszkodliwej alienacji, należy dokonać sanacji aktu nieważnego”. A. Domaszk (Dobra..., 276) wskazuje, że „jeśli wystąpiły drobne niedociągnięcia formalne, należy rozważyć sanację aktu nieważnego. W sytuacji naruszenia istotnych norm kanonicznych, podmioty władzy kościelnej mogą wykorzystać możliwości prawne, jakie daje ustawodawstwo państwowe, aby przywrócić stan posiadania lub dochodzić naruszonej sprawiedliwości”.

${ }^{68}$ T. PAwluk (Prawo..., s. 52) wskazuje, że „skarga osobowa (...) jest kierowana przeciwko temu, który bezprawnie dokonał alienacji, bądź jego spadkobiercom, natomiast skarga rzeczowa (...) - przeciwko każdemu posiadaczowi rzeczy nieważnej alienowanej; pierwsza ma na celu uzyskanie odszkodowania, druga zaś - zwrot rzeczy".

${ }^{69}$ P. Kaleta (Kościelne..., s. 226-227) wskazuje m.in. następujące podstawy prawne takiego działania: kan. 128, kan. $1445 \$ 1$ pkt 1, kan. 1491, kan. $1729 \$ 1$ KPK. 
będzie jednocześnie ważna i skuteczna na forum świeckim (będzie wywoływać skutki cywilnoprawne i prowadzić np. do przeniesienia własności określonych dóbr na inny podmiot ${ }^{70}$. Wynika to ze szczególnych wymogów przewidzianych dla ważności alienacji na forum kościelnym, które jednocześnie nie są wymagane dla ważności takiej czynności na gruncie prawa cywilnego ${ }^{71}$. Kościelne prawo majątkowe rozróżnia zatem kanoniczną i cywilnoprawną skuteczność aktu alienacji i zakłada możliwość cywilnoprawnej ważności kanonicznie nieważnej alienacji. Kwestia ta zostanie szerzej omówiona w drugim artykule.

Należy zauważyć, że konsekwencją alienacji dóbr kościelnych bez dochowania kanonicznych wymogów może być również odpowiedzialność karna osoby dokonującej takiej alienacji ${ }^{72}$. Zgodnie z kan. 1377 KPK, kto alienuje dobra kościelne bez przepisanego prawem zezwolenia, powinien być ukarany sprawiedliwą karą $^{73}$.

Warto w tym miejscu także zauważyć, że złe zarządzanie dobrymi doczesnymi (a alienację dokonaną bez dochowania prawnych wymogów można za takie uznać) może stać się także powodem usunięcia

\footnotetext{
${ }^{70}$ A. Domaszk, Zarzqdizanie..., s. 304; P. Kaleta, Komentarz..., s. 116.

${ }^{71}$ P. Kaleta, Komentarz..., a. 101. A. Domaszk (Dobra..., s. 273) zauważa, że „niedopełnienie norm prawa kanonicznego wiązać się może z kolei z kategorią nieważności aktu prawnego w prawie kościelnym, a jednocześnie z ważnością tego aktu w prawie cywilnym. Powstaje wówczas rozdźwięk. W takiej sytuacji kompetentna władza kościelna winna podjąć decyzję, po uprzednim rozważeniu wszystkich okoliczności, czy wystąpić na drogę sądową".

72 T. Pawluk, Prawo..., s. 52; M. Sitarz, Warunki..., s. 111; P. Kaleta, Komentarz..., s 117; Tenże, Kościelne..., s. 227; A. Domaszk, Dobra..., s. 274; Tenże, Zarzadzanie..., s. 304-305; M. TомкiEwicz, Obrót..., s. 40-41. Szerzej kwestię tę omawia L. Świto (Alienacja..., s. 145-150).

${ }^{73}$ P. Kaleta (Kościelne..., s. 227) zauważa, że kan. 2347 Kodeksu Prawa Kanonicznego z 1917 r. „przewidywał nawet karę ekskomuniki przeciwno tym, którzy alienowali dobra kościelne bez uzyskania wymaganego do ważności zezwolenia Stolicy Apostolskiej. W innych wypadkach były nakładane kary grzywny (podwójna wartość uzyskanych zysków) i pozbawienie urzędu”. Kwestię tę porusza również L. Świto (Alienacja..., s. 149-150).
} 
proboszcza z urzędu ${ }^{74}$. Zgodnie z kan. 1741 pkt 5 KPK, przyczyną, dla której proboszcz może być usunięty z parafii zgodnie z przepisami prawa, jest złe zarządzanie dobrami doczesnymi, z wielką szkodą Kościoła, ilekroć na zaradzenie złu brak innego środka.

\section{Zakończenie}

Możliwość alienacji dóbr doczesnych jest wrodzonym prawem Kościoła. Jednocześnie, jednym z najważniejszych celów kościelnego prawa majątkowego jest ochrona tych dóbr ${ }^{75}$. Alienowanie stałego majątku publicznej osoby prawnej oraz rzeczy darowanych Kościołowi na podstawie ślubu, rzeczy kosztownych $\mathrm{z}$ racji artystycznych lub historycznych, jak również relikwii i obrazów, które w jakimś kościele doznają wielkiej czci wiernych, bądź też dokonanie innej transakcji, przez którą stan majątkowy kościelnej osoby prawnej może ulec pogorszeniu, jest uzależnione od dochowania przewidzianych prawem kanonicznym wymogów, stanowiących warunki ważności i godziwości takiego aktu.

Kanoniczne wymogi alienacyjne są liczne i zróżnicowane. Zaliczyć do nich można m.in. konieczność uzyskania zezwolenia (biskupa diecezjalnego lub innej kompetentnej władzy, a czasem również Stolicy Świętej), którego udzielenie poprzedzić musi uzyskanie zgody kolegialnych organów doradczych (rady do spraw ekonomicznych i kolegium konsultorów) oraz zainteresowanych osób, uzyskanie pisemnej wyceny alienowanych dóbr i nie dokonywanie alienacji za kwotę niższą od wskazanej w wycenie, istnienie słusznej przyczyny alienacji, stosowne przeznaczenie środków uzyskanych $\mathrm{z}$ alienacji oraz zachowanie innych, przewidzianych przez kompetentną władzę, środków ostrożności. Konieczność spełnienia określonych wymogów

${ }^{74}$ A. Domaszk, Dobra..., s. 275, Tenże, Zarzadzanie..., s. 305. P. Kaleta (Kościelne..., s. 227) zauważa jednak, że „we wspomnianym kanonie jest mowa o złym zarządzaniu, a nie o wadliwej alienacji”.

${ }^{75}$ A. Domaszk (Dobra..., s. 248-249) wskazuje, że „najważniejszym celem norm o alienacji jest ochrona posiadania dóbr kościelnych. Ale chodzi również o uszanowanie woli wiernych i innych ofiarodawców, aby dobra kościelne służyły realizacji celów Kościoła (kan. 1254)”. 
alienacyjnych uzależniona jest jednocześnie od wartości oraz rodzaju dóbr kościelnych ${ }^{76}$, będących przedmiotem alienacji bądź innej transakcji, na skutek której majątek kościelnej osoby prawnej może się znaleźć w gorszej sytuacji.

W związku z dokonaną przez prawodawcę kościelnego kanonizacją przepisów prawa państwowego dotyczących umów i zobowiązań, za kanoniczny warunek ważności alienacji trzeba uznać także dochowanie określonych dla takiej czynności wymogów, wynikających z prawa cywilnego.

Niedochowanie kanonicznych wymogów alienacyjnych wiąże się z nieważnością lub niegodziwością aktu alienacji na forum kościelnym. Taka alienacja może być jednak sanowana przez kompetentną władzę. Jednocześnie kościelne prawo majątkowe zakłada możliwość cywilnoprawnej ważności kanonicznie nieważnej alienacji. Kwestia skuteczności takiej alienacji oraz możliwości uznania kanonicznych wymogów alienacyjnych za przesłanki ważności czynności dokonywanych przez kościelne osoby prawne na forum świeckim będzie przedmiotem rozważań zawartych w kolejnym artykule.

\section{Alienation carried out without respecting the canonical terms}

This is the first of two articles presenting the consideration of the canonical and civil-law effectiveness of goods alienation, carried out by ecclesial legal person without meeting the requirements of canon law. The consideration covered in the article constitutes the attempt to find answers to questions of whether the canonical alienation requirements are binding on the secular forum, as well as the question of the effectiveness of alienation

${ }^{76}$ M. Tомкіеwicz (Obrót..., s. 42) zauważa, że „uzyskanie zgody kompetentnych podmiotów jest warunkiem sine qua non ważnej alienacji. To, jaki konkretnie podmiot jest podmiotem 'kompetentnym' dla udzielenia zezwolenia na dokonanie określonych czynności alienacyjnych uzależnione jest od kilku kryteriów: od charakteru podmiotu, który o ową zgodę występuje, od charakteru przedmiotu alienacji oraz - w pewnych przypadkach - od jej wartości”. 
carried out without respecting those requirements within the canon law and Polish civil law.

This article contains the consideration concerning the alienation of church property, as well as its canonical requirements, the canonization of the civil law regulations concerning the contracts and obligations, as well as canonical effectiveness of alienation carried out without respecting the legal terms.

The next article shall present the consideration of the reception of canon law to the Polish legal system, as well as civil-law effectiveness of alienation carried out by ecclesial legal person, without respecting the canonical terms.

SŁOWA KLUCZOWE: alienacja; transakcje, które mogą pogorszyć stan majątkowy osoby prawnej; patrimonium stabile; dobra doczesne kościoła; kościelne prawo majątkowe; kanonizacja prawa cywilnego

KEYWORDS: alienation; transactions which can worsen the patrimonial condition of a juridic person; patrimonium stabile; the temporal goods of the church; ecclesiastical patrimonial law; canonization of the civil law

\section{NOTA O AUTORZE}

MGR LIC. ARKAdiUsz Mróz - prawnik, prawnik kanonista; wykładowca na Wydziale Prawa Kanonicznego Uniwersytetu Kardynała Stefana Wyszyńskiego w Warszawie. 